\title{
Strengthening threatened communities through adaptation: insights from coastal Mozambique
}

\author{
Jessica L. Blythe ${ }^{1}$, Grant Murray ${ }^{2}$ and Mark Flaherty ${ }^{1}$
}

\begin{abstract}
Change is a defining characteristic of coastal social-ecological systems, yet the magnitude and speed of contemporary change is challenging the adaptive capacity of even the most robust coastal communities. In the context of multiple drivers of change, it has become increasingly important to identify how threatened communities adapt to livelihood stressors. We investigate how adaptation is negotiated in two coastal fishing communities by documenting livelihood stressors, household assets, adaptive strategies, and factors that facilitate or inhibit adaptation. Declining catch is the most common stressor being experienced in both communities, however, socioeconomic, e.g., disease or theft, and ecological, e.g., severe storms and drought, changes are also creating livelihood stress. We find that specialized fishers' with higher investment in fishing gear and government support are adapting by intensifying their fishing efforts, whereas poorer fishers with more livelihood options are adapting through diversification. Adaptation is facilitated by fishers' groups, occupational pride, and family networks. It is inhibited by limited assets, competition over declining resources, and pervasive poverty. Our data suggest that adaptation is a heterogeneous process that is influenced by multiple factors. Understanding the complexity of fishers' responses to livelihood stressors is critical for fostering adaptive capacity in coastal communities, for strengthening fisheries management, and for improving the livelihoods of fishing dependent communities.
\end{abstract}

Key Words: adaptation; Africa; diversification; intensification; livelihoods; small-scale fisheries

\section{INTRODUCTION}

Coastal communities are facing increasing challenges to their daily livelihoods. Although social-ecological systems evolve to accommodate variability, coastal systems are facing new sources of change linked, for example, to overfishing, climate change, and global economic liberalization (O'Brien and Leichenko 2000, Lotze et al. 2006, Badjeck et al. 2010). These new challenges have the potential to push marine social-ecological systems past their experienced range of variability and thus have immense consequences for the well-being of hundreds of millions of people whose livelihoods depend on fisheries, particularly in the developing world (Perry et al. 2010). Further, social and ecological changes in coastal systems interact across spatial and temporal scales creating challenges that are complex, reoccurring, and often hard to detect (Khan and Neis 2010). Jentoft and Chuenpagdee (2009) have argued that these types of challenges should be characterized as wicked problems, meaning they are difficult to define, vary depending on perspective, and cannot be solved absolutely the way a math problem can be solved but rather tend to reappear. Given the vulnerability of small-scale fishing communities to these wicked problems, researchers have highlighted the importance of understanding how fishers are adapting to contemporary coastal change (MEA 2005, Daw et al. 2009). This paper builds on our understanding of how threatened coastal communities adapt to multiple drivers of change by analyzing how adaptation is negotiated in two smallscale fishing communities along Mozambique's central coast.

Adaptation refers to adjustments in social-ecological systems' behavior that are carried out in response to observed or anticipated changes to reduce damaging impacts or to take advantage of new opportunities (Smit and Wandel 2006, IPCC 2007). Adaptation is a continuous stream of activities, choices, and actions by various actors that occurs across multiple scales (Adger et al. 2005, Osbahr et al. 2010). Adaptation is not a homogeneous process, but rather one that is influenced by factors such as economic and technological development, social values, culture and class (Coulthard 2008, Nielsen and Reenberg 2010). In much of the developing world, a large extent of adaptation will be enacted at the local level because national scale adaptation initiatives are constrained by limited financial and human resources (Hervey and Blythe 2013). Accordingly, much research has focused on factors that influence adaptive capacity in resource-dependent communities at the local scale, but these factors remain better researched for agricultural systems than for fisheries (Daw et al. 2009). By focusing on fishing livelihoods, this paper illustrates how fishers are responding to stressors and identifies factors that facilitate or inhibit adaptive strategies in rural fishing communities.

Fishing livelihoods provide a particularly useful platform for analyses of adaptation because they are known for being complex, dynamic, and reactive to multiple drivers of change (Allison and Ellis 2001). As with adaptation, livelihoods can be understood as the choices and actions that people take to earn a living, meet their consumption needs, cope with uncertainty, and respond to new opportunities (de Haan and Zoomers 2005). Chambers and Conway (1992) proposed the livelihoods approach as a means for understanding the complexity of rural peoples' lives. The livelihood approach seeks to unravel how patterns of assetholding and institutional structures can create differential capacities for rural households in coping with periods of stress (Scoones 2009). In the livelihoods literature, assets are divided into five categories: financial capital (savings, credit), human capital (education, health), natural capital (land, trees, fish stocks), physical capital (infrastructure, material possessions), and social capital (kinship networks, associations; Carney 1998, Allison and Ellis 2001). Of interest is how people draw on various assets in response to multiple drivers of change. Understanding how livelihood adaptation is negotiated at the household level is critical for strengthening existing adaptive capacity in small-scale fishing communities, for improving fisheries management, and 
for rebuilding threatened communities (Allison and Ellis 2001, Khan and Neis 2010).

During the last 30 years, coastal communities in Mozambique have adapted to declining fish stocks, periods of war, and economic transition and are now being confronted by the impacts of climate change (Blythe et al. 2013). The extensive small-scale fishing sector in Mozambique thus provides a suitable case for examining how patterns of asset holdings affect households' capacity to respond to multiple drivers of change. Adaptive actions are influenced by antecedent social and cultural institutions and values, which are embedded in complex ecological and biophysical contexts making the social-ecological context a critical entry point for the analysis of adaptation (Adger 2003, Berkes et al. 2003, Ommer et al. 2011).

\section{Drivers of change in the small-scale fishery}

Mozambique is located on the southeast coast of Africa and is endowed with rich marine resources. Its coast, the third longest in Africa $(2700 \mathrm{~km})$, is lined by sandy beaches, mangroves, sea grass beds, and coral reefs in the north and south (FAO 2007). The small-scale fishery, which employs more than 280,000 fishers, is a multispecies fishery focused primarily on shallow-water shrimp (e.g., Acetes erythraeus) and small pelagics such as sardines and anchovies, while the industrial fleet targets tuna and prawn, the country's most valuable export species (FAO 2007, IDPPE 2009).

During the last few decades, climatic stressors have become more prevalent along the coast. In recent years, both the frequency and severity of tropical storms have increased. For example, of the 15 cyclones that entered the Mozambique Channel and made landfall between 1980 and 2007, only 4 occurred between 1980 and 1993, while the other 11 occurred between 1994 and 2007 (van Logchem and Brito 2009). In 1998, an El Niño event led to mass coral bleaching in the northern part of the country (Muthiga et al. 2008). Mozambique is also vulnerable to droughts and inland flooding (IPCC 2007). In 2000, heavy rains ruptured the banks of the Zambezi river creating widespread flooding that left 800 people dead, and displaced over half a million people (Christie and Hanlon 2001).

In addition to these climactic stressors, socioeconomic changes are adding pressure to coastal social-ecological systems. In 1975, Mozambique became independent from Portugal and the new government established a one-party socialist state. For the smallscale fisheries sector, this meant state intervention. The government began to supply fishing materials and consumer goods to coastal communities and to purchase, distribute, and sell fish from small-scale fishers to national and international markets through fishing cooperatives called combanados pesqueiros (Menezes et al. 2009). Two years after independence, civil war erupted between the ruling Mozambique Liberation Front (FRELIMO) and the anticommunist Mozambique Resistance Movement (RENAMO). Inland fighting drove up to four million people to the coast, adding pressure to the inshore fishery (Lopes and Gervásio 1999). Mozambique's economy, which was weakened during the independence war, continued to deteriorate during the civil war (1977-1992). In 1987, the nation began the transition from socialism to capitalism under the direction of the International Monetary Fund's structural adjustment programs. This period was characterized by the sale of state assets to private buyers and the removal of statecontrolled markets (Pitcher 2002). Economic liberalization led to the abolition of the extensive fishing cooperatives along the coast and to the erosion of living conditions in many fishing communities (Menezes et al. 2009).

Living conditions in coastal communities have also been negatively affected by declining catch rates. Total marine national landings peaked around the mid-1980s and steadily declined until 2003 (FAO 2011). Although no data exist for the small-scale sector prior to 2003, catch reconstructions suggest that small-scale landings followed a similar trend as the industrial sector and peaked in the mid-1980s (Jacquet et al. 2010, Blythe et al. 2013). These trends suggest that critical fisheries resources are overexploited. Today, Mozambique is one of the poorest countries in the world. The United Nations Development Programme ranks it as 185 out of 187 countries on the human development index (UNDP 2013). In 2009, over half of the population was living below the national poverty line of 18 meticais or US\$0.50 a day (GoM 2011). Formal employment is extremely limited. Consequently, the small-scale fishery provides one of the few reliable livelihood options for over 12 million coastal people (IDPPE 2009), livelihood options that are currently in jeopardy.

\section{METHODS}

\section{Research communities}

A comparative case study approach is a useful way to illuminate the interactions between differential assets patterns and adaptive strategies. Our two research communities, Zalala Beach and Inhangome (Fig. 1), were chosen because fishing is the primary occupation of men in both communities yet their assets, government support and fishing techniques differ.

Fig. 1. Location of the research communities, Inhangome and Zalala Beach, in Mozambique.

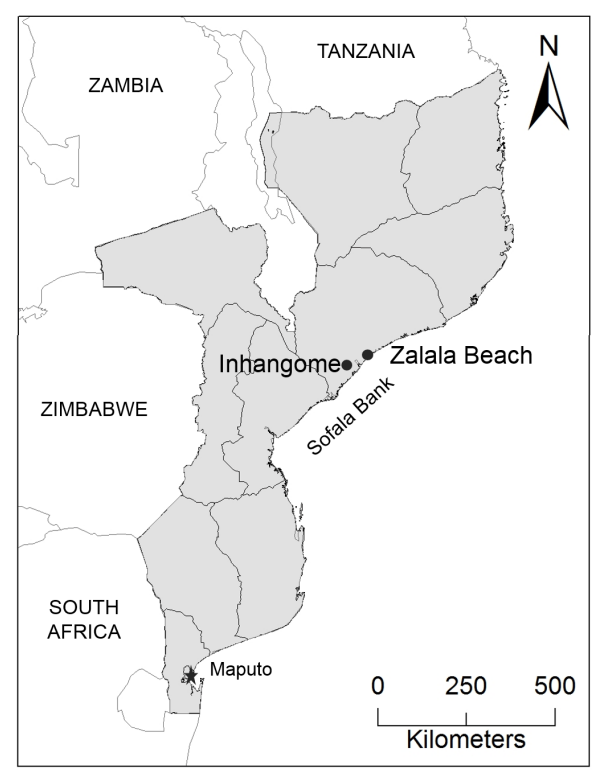


Inhangome (population 1250) lies on the Rio dos Bons Sinais, 25 kilometers from the Indian Ocean, in Zambezia, one of Mozambique's poorest provinces. The majority of fishers in Inhangome are born and raised in the community. Fishers use dugout canoes (3-4 m) in the estuary, fish with small nets, hand lines, or basket traps and target small shrimp, fish, and crab. The majority of catch is consumed by the household. A small portion is sold fresh to middlemen called compradores who sell it in Quelimane, the closest urban centre. Inhangome is separated from Quelimane by a 10 kilometer footpath and is inaccessible by motorized vehicle. Poverty is pervasive and living conditions are very poor. Electricity is limited and the only community well contains brackish water.

Zalala (population 2690) is located along the productive Sofala Bank 30 kilometers north of Inhangome. Fishers use wooden vessels (called lanchas or canoa typo moma) that are typically 9-10 meters in length and accommodate crews of up to twenty fishers. Lanchas are primarily rowed or sailed. Fishers use long $(>100 \mathrm{~m})$ seine nets along the beach and gill nets in the open ocean (IDPPE 2009). They focus primarily on shallow-water shrimp and pelagic fish. Catch is consumed locally and sold fresh to compradores who sell it throughout Zambezia. Poverty is prevalent, but fishers at Zalala benefit from government investment in infrastructure, including the construction of community wells and the maintenance of a tarmacked road between Zalala and Quelimane, and fisheries extension support. Zalala Beach is being targeted by the government as an emerging small-scale fishing growth pole and is the planned site for a regional fishing market (H. Manjor, Institute for the Development of the Small-Scale Fishery (IDPPE), personal communication). The majority of fishers have migrated from other communities or provinces to fish at Zalala Beach.

\section{Data collection}

To assess local adaptation to livelihood stressors, we collected empirical data between 2009 and 2012. In order to develop research questions that were characteristic of local conditions, we conducted a scoping trip in 2009, which allowed us to consult with fisheries researchers at the University of Eduardo Mondlane's School of Marine and Coastal Science and fisheries officers at the Ministry of Fisheries' Institute for the Development of Small-Scale Fisheries (IDPPE). The scoping trip also permitted us to discuss our proposed research with the village head (called Secretaria do Bairro), the chief, and members of fishers' groups in both communities.

The main unit of analysis was the household, which we defined as those living in the same compound. Household surveys (Zalala Beach $n=93$, Inhangome $n=42$ ) were conducted in September and October 2010. We purposefully selected fishing households by approaching fishers on the beach. Every second fisher encountered was asked to participate. Survey questions were developed based on the 2009 scoping trip and were divided into four categories: fishers' demographics (age, number of dependents), livelihood stressors, household assets, and adaptive strategies. Each category consisted of a quantitative closed set of questions (list of potential stressors, assets, and adaptive strategies) followed by an open-ended section so that fishers could add items that were not included in the initial list. To determine adaptation strategies, we asked fishers what stressors (dificuldades) they had experienced during the previous 12 months and how they adapted to those stressors (como você resolveu essas dificuldades?).

Next, we conducted qualitative, semistructured interviews to add experiential data to the trends that emerged from the quantitative surveys (McGoodwin 2001). Interview participants were identified by the village head and an IDPPE extension agent, and then through snowball sampling. Interviews (Zalala Beach $n=$ 17, Inhangome $n=12$ ) were conducted in Sena, Chuabo, or Portuguese, according to respondents' preference, between October and December 2010. All survey and interview respondents were male. In 2011, we coded interviews for emergent themes. In May 2012, we returned to Mozambique and conducted a focus group with fishers in both communities. We presented a summary of our results from the 2010 fieldwork, and made adjustments and added clarifications as necessary. The time spent in Mozambique (seven months), the mixed methods (quantitative-qualitative) approach, plus repeat visits to communities over a three-year period enabled validation of the research findings.

\section{RESULTS AND ANALSYIS}

\section{Livelihood stressors}

Small-scale fishers are continuously exposed to multiple livelihood stressors that necessitate changes in their behaviour to mitigate damages and to take advantage of opportunities. Here, we present the livelihood stressors being confronted by fishers in our two research communities (Fig. 2). Two important points emerge from the data. First, the most common stressor being experienced by both communities is declining catch rates. This is significant because declining catch rates threaten the food security and livelihoods of hundreds of thousands of people living along the Mozambican coast. Second, despite the fact that these are fishing communities, livelihood stressors are not restricted to fishing activities and resources. Rather, livelihood stressors arise from socioeconomic (e.g., disease, theft, and food insecurity) and ecological (e.g., severe storms or drought) sources. These results build on the work of Mills et al. (2011), who demonstrate that fishing communities in Mali and Nigeria rank vulnerabilities related to basic human needs as more critical than vulnerabilities relating to the fishery.

\section{Fishers' assets}

At first, Zalala Beach appears to be a relatively affluent fishing community. For example, fishers use large lancha boats and seine nets that can measure more than 100 meters in length. The majority of fishers have access to clean drinking water and a formal hospital (Table 1). In addition, since the early $2000 \mathrm{~s}$, the IDPPE has assisted in the development of formal fishers' groups (called conselho comunitário depesca, $\mathrm{CCP}$ ) and the majority of fishers at Zalala belong to a fishers' group (Table 1).

In contrast, Inhangome is a poor fishing community. All respondents fish from small dugout canoes and, although more respondents from Inhangome own nets than at Zalala, their nets are smaller and less expensive. Very few fishers have access to clean drinking water and over half of fishers who report having access to a doctor use a traditional healer rather than a formal hospital (Table 1). The community is too small to receive government fishing extension support. Less than a third of fishers belong to a fishers' group (Table 1). 
Fig. 2. Summary of livelihood stressors being experienced in the two research communities. Bars indicate percentage of total respondents $( \pm 95 \% \mathrm{CI})$ that experienced each stressor in the previous 12 months.
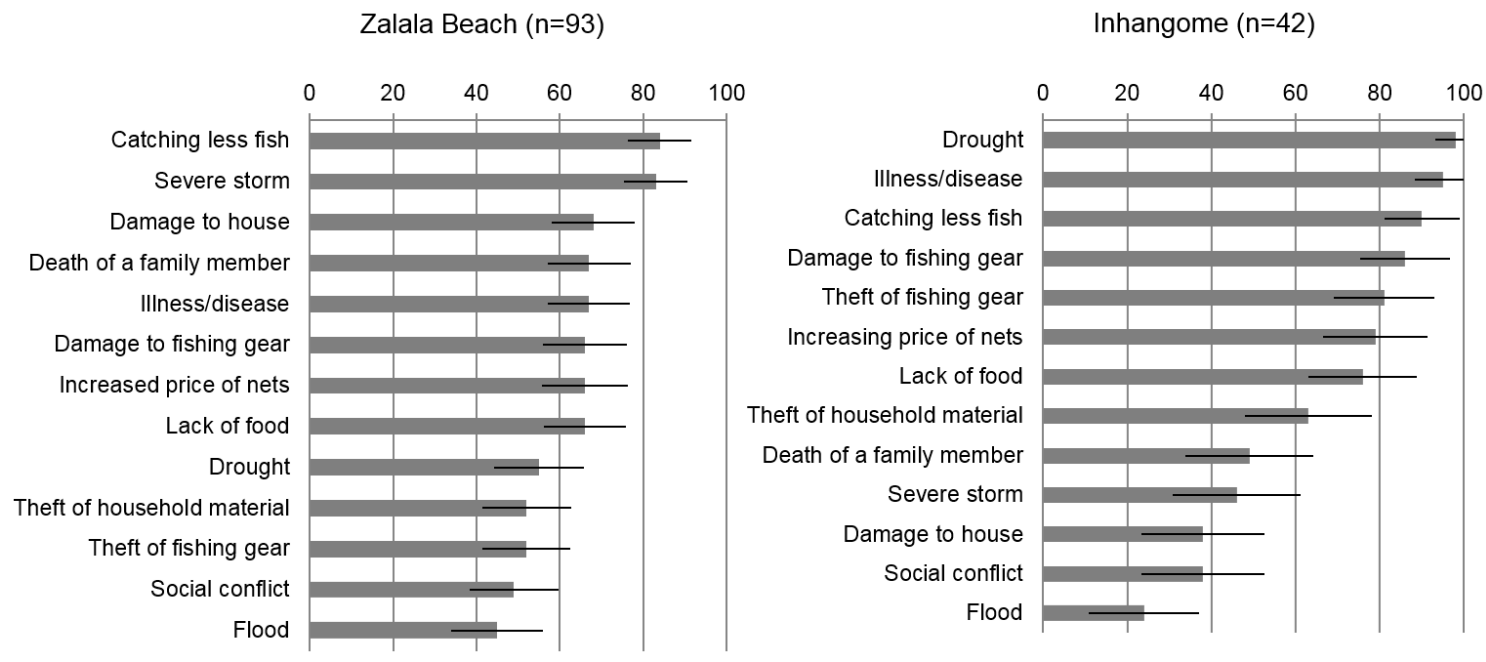

As we spent time in the two communities, however, it became clear that although expensive fishing gear and government support are lacking in Inhangome, fishers have other types of assets. In fact, assets are higher in 12 of the 18 asset categories in Inhangome (Table 1). For example, fishers from Inhangome have higher school attendance, higher literacy rates, and better access to school for their children. In Inhangome, $26 \%$ of fishers' houses have roofs made of metal, as opposed to grass. By comparison, only $8 \%$ of respondents' roofs are metal at Zalala Beach. We used metal roofs as a proxy for wealth because metal is a more expensive material and fishers in both communities articulated that it was the preferred roofing material. Fishers from Inhangome have more subsistence gardens (called machambas) and higher social capital. The majority (71\%) of fishers from Inhangome were born in that community, whereas only $12 \%$ of fishers at Zalala Beach were born at Zalala Beach. That is, fishers at Zalala Beach can be characterized as highly invested in the coastal fishery: they fish with expensive sea-worthy gear, receive government support, and have migrated following the fish, whereas their nonfishing-related assets are relatively low. In Inhangome, expensive fishing gear is limited, but other assets including natural, human, and social capital are high.

\section{Adaptive responses to livelihood stressors}

Fishers' along the Mozambican coast have been resourceful in adapting to changing conditions and have developed a combination of fishing (intensification) and nonfishing (diversification) strategies in response to livelihood stressors (Table 2).

\section{Adaptive strategies: intensify or diversify}

In interviews, fishers at Zalala indicated that their primary response to periods of stress is to intensify their fishing effort. In response to declining inshore catches, they have shifted from fishing in the shallow waters along the beach with seine nets to fishing in the open ocean with gill nets. They have also increased the length of individual fishing trips, begun fishing in the dark and started spending the night at sea. Beyond this, fishers at Zalala have begun purchasing blocks of frozen bycatch from industrial shrimp trawlers at sea and selling them at the beach to supplement their own lower catch rates. When asked what would improve their ability to adapt to future livelihood stressors, fishers identified improved fishing capacity including bigger nets, semi-industrial boats, motors for their boats, as well as better preservation methods (e.g., Coleman coolers, salting tanks, and freezers). Both their current adaptive strategies and their ideas for improving those strategies are based almost entirely on the fishery where, despite the challenges, all of those interviewed indicated that they desired to remain. Similar trends are observable in India, where specialized fishers demonstrate a lower capacity to diversify, and in East Africa, where higher infrastructure development and greater economic wealth are associated with reduced readiness to exit a declining fishery (Coulthard 2008, Cinner et al. 2011, Daw et al. 2012).

Alternatively, the primary adaptation strategy used by fishers in Inhangome to deal with difficult periods is to diversify their livelihoods. In response to livelihood stress, $67 \%$ of survey respondents participated in nonfishing related work (Table 2). Nonfishing work included: small business such as the sale of clothing, alcohol, or chickens $(\mathrm{n}=12)$, work in the machamba $(\mathrm{n}$ $=8)$, collection and sale of wood from mangroves for fuel $(\mathrm{n}=$ $5)$, casual labor in Quelimane $(\mathrm{n}=2)$, or work as a bicycle mechanic $(n=1)$. The choice to diversify may be related to the relatively broader nature of their asset base, compared to those at Zalala Beach. For example, $97 \%$ of Inhangome fishers have a machamba in their community. By contrast, although $64 \%$ of fishers at Zalala Beach have machambas, most are located in their community of origin not Zalala Beach and are therefore not available as an alternative livelihood. Research in Kenya and Tanzania has found that households with higher livelihood options are more likely to engage in livelihood diversification (Cinner et al. 2009, 2011). 
Table 1. Summary of assets across the two study communities. Values indicate the proportion of total respondents in each community who positively identified ownership of or access to each asset in household surveys.

\begin{tabular}{|c|c|c|}
\hline & \multicolumn{2}{|c|}{$\begin{array}{l}\text { Respondents by area } \\
\text { Proportion of } n\end{array}$} \\
\hline & $\begin{array}{c}\text { Zalala Beach }(\mathrm{n}= \\
93)\end{array}$ & $\begin{array}{l}\text { Inhangome }(\mathrm{n}= \\
42)\end{array}$ \\
\hline \multicolumn{3}{|l|}{ Financial } \\
\hline Savings & $0.54( \pm 0.10)^{\dagger}$ & $0.31( \pm 0.15)$ \\
\hline \multicolumn{3}{|l|}{ Human } \\
\hline Access to a doctor & $0.98( \pm 0.10)$ & $0.81( \pm 0.09)$ \\
\hline $\begin{array}{l}\text { Access to a school for } \\
\text { your children }\end{array}$ & $0.66( \pm 0.10)$ & $0.90( \pm 0.09)$ \\
\hline Literacy & $0.56( \pm 0.10)$ & $0.86( \pm 0.11)$ \\
\hline Primary education & $0.70( \pm 0.09)$ & $0.74( \pm 0.13)$ \\
\hline Secondary education & $0.12( \pm 0.07)$ & $0.17( \pm 0.11)$ \\
\hline \multicolumn{3}{|l|}{ Natural } \\
\hline Access to fish & 1.00 & 1.00 \\
\hline Livestock/poultry & $0.49( \pm 0.11)$ & $0.54( \pm 0.16)$ \\
\hline Machamba & $0.64( \pm 0.10)$ & $0.97( \pm 0.05)$ \\
\hline \multicolumn{3}{|l|}{ Physical } \\
\hline Access to a well & $0.86( \pm 0.07)$ & $0.36( \pm 0.14)$ \\
\hline Bicycle & $0.28( \pm 0.09)$ & $0.36( \pm 0.14)$ \\
\hline Boat $^{\S}$ & $0.62( \pm 0.10)$ & $0.69( \pm 0.14)$ \\
\hline Cell phone & $0.30( \pm 0.13)$ & $0.21( \pm 0.16)$ \\
\hline House & $0.96( \pm 0.13)$ & $0.98( \pm 0.05)$ \\
\hline Net & $0.56( \pm 0.10)$ & $0.86( \pm 0.11)$ \\
\hline \multicolumn{3}{|l|}{ Social } \\
\hline Belong to a fishers' group & $0.69( \pm 0.09)$ & $0.29( \pm 0.14)$ \\
\hline $\begin{array}{l}\text { Family members in the } \\
\text { community }\end{array}$ & $0.77( \pm 0.09)$ & $0.98( \pm 0.05)$ \\
\hline Spouse & $0.73( \pm 0.09)$ & $0.86( \pm 0.11)$ \\
\hline \multicolumn{3}{|c|}{$\begin{array}{l}\text { Indicates } \pm \text { margin of error at } 95 \% \text { confidence interval. } \\
\text { At Zalala, } 76 \% \text { use a hospital and } 12 \% \text { use a courandeiro (local term } \\
\text { for traditional healer). In Inhangome, } 38 \% \text { of respondents use a } \\
\text { hospital and } 53 \% \text { use a courandeiro. } \\
\$ \text { At Zalala Beach } 94 \% \text { of vessels are large wooden lancha boats, } 6 \% \\
\text { are dugout canoes. In Inhangome, all boats are dugout canoes. } \\
\text { 'At Zalala, } 92 \% \text { of respondents' houses have grass roofs and } 8 \% \text { metal } \\
\text { roofs. In Inhangome, } 74 \% \text { of respondents' houses have grass roofs and } \\
26 \% \text { have metal roofs. }\end{array}$} \\
\hline
\end{tabular}

\section{Factors that facilitate adaptation}

Our data suggest that adaptation is facilitated by fishers' groups, occupational pride, and family networks. Fishers' groups play an important role in enabling fishers to transcend the limitations of individual adaptive actions. At Zalala, $69 \%$ of survey respondents belong to fishers' groups (Table 1), which provide many important services to their members including advocating for fishers' interests to government, NGOs, and other institutions. The groups are also responsible for intercommunity conflict resolution and enforcement of fishing regulations. By establishing saving and lending groups (called poupança e crédito rotativo, PCR) and helping fishers prepare financial loan documents, fishers' groups help fishers obtain credit for fishing gear and licenses. A 44-year-old fisher from Zalala explained, "It's very good to be part of a fishers' group. It helps a lot when it's time to pay for your fishing license. When you have any problems they help right away. Full support.” By representing fishers' interests to government and NGOs, mitigating intercommunity conflict, and facilitating access to credit, fishers' groups increase fishers' ability to adapt to livelihood stressors.

Table 2. Adaptive strategies in response to livelihood stress across the study areas. Values indicate the percentage of total survey respondents in each community who identified using each adaptive strategy during the previous 12 months.

\begin{tabular}{lcc}
\hline \hline & \multicolumn{2}{c}{$\begin{array}{c}\text { Respondents by area } \\
\text { Proportion of } \mathrm{n}\end{array}$} \\
\cline { 2 - 3 } & Zalala Beach $(\mathrm{n}=93)$ & Inhangome $(\mathrm{n}=42)$ \\
\hline $\begin{array}{l}\text { Extra work } \\
\text { (nonfishing) }\end{array}$ & $33( \pm 0.10)^{\ddagger}$ & $67( \pm 0.14)$ \\
Increase fishing effort & $37( \pm 0.10)$ & $26( \pm 0.13)$ \\
Loan from bank & $3( \pm 0.04)$ & $2( \pm 0.05)$ \\
Loan from family & $48( \pm 0.11)$ & $70( \pm 0.14)$ \\
Sale of fishing gear & $12( \pm 0.07)$ & $10( \pm 0.09)$ \\
Sale of livestock/ & $30( \pm 0.10)$ & $50( \pm 0.15)$ \\
poultry & & $71( \pm 0.14)$ \\
Taking less food & $73( \pm 0.09)$ & $32( \pm 0.14)$ \\
Use of savings & $55( \pm 0.11)$ & \\
${ }^{\dagger}$ Fishers perform more than one type of adaptive strategy. \\
${ }^{\ddagger}$ Indicates \pm margin of error at $95 \%$ confidence interval.
\end{tabular}

Despite the fact that fishing is often characterized as a last resort livelihood option for the poorest of the poor, many fishers demonstrate a strong sense of occupational pride that motivates them to adapt in ways that will allow them to remain fishing (Pollonac et al. 2001, Béné 2003). A sense of occupational pride is evident at Zalala Beach: for example, a 28-year-old fisher explained that he chose to become a fisher, "because I observed other fishers who were living dignified lives." The prospect of living a dignified life, by participating in the prestigious coastal fishery, may also be a motivating factor drawing fishers from other parts of the country to fish at Zalala Beach. A 38-year-old fisher said that he became a fisher "because being a trader wasn't enough, so I sold my motorbike and bought my first net [9 years ago]. After five years I bought my second net. Today I have five fishing nets." Fishers at Zalala participate in what has historically been a lucrative profession and they form the economic core of the community. Despite recent declines in catch rates and reduction in income from fishing, there is a strong sense of attachment to occupation, which may contribute to fishers' decision to adapt through fishing-based strategies.

In Inhangome, family networks play an important role in facilitating adaptation during difficult times. Most fishers were born and raised in the community $(71 \%)$ and have extended family in the community (98\%) (Table 1 ). By comparison, only $12 \%$ of fishers from Zalala Beach were born at Zalala Beach. Fishers identified loans from family as critically important during periods of stress (Table 2). Family members also helped fishers adapt by contributing multiple sources of income. Polygamy is common in 
rural Mozambique. A standard fishing household consists of a male fisher and several wives and children. Typically, the husband fishes and the wife engages in a range of livelihood activities, such as growing crops in the machamba, collecting firewood, and managing the household activities, finances, and children. This helps to diversify household livelihood activities. A 42-year-old fisher explained, "When I'm fishing, my family is in the machamba. In the end, we put all the yields together and it helps us overcome our difficulties." Families also provide emotional support: a 23-year-old fisher said that, "family accompany you to the hospital, they help you when you are sick by talking with you to distract you and telling you jokes." The strategy of drawing on social capital, such as family networks, for support during periods of stress has also been shown to increase fishers' adaptive capacity in West Africa (Perry et al. 2010).

\section{Factors that inhibit adaptation}

Our results suggest that limited assets, competition over declining resources, and poverty inhibit successful adaptation among smallscale fishers. At Zalala Beach, most assets are low. For example, only half of fishers are literate and only $12 \%$ have attended secondary school (Table 1). These limited assets may reduce fishers' adaptive options, thereby confining them to fishing-based adaptation strategies. Low literacy rates, for example, can limit access to wage work in urban areas. Significantly, during times of stress, only one in three fishers at Zalala took work outside of the fishery (Table 2). A 30-year-old fisher described feeling locked in the fishery because of a lack of alternative options by explaining, when asked if he wanted to continue fishing, "yes, because fishing is the only thing I know how to do." Many fishers expressed concern about their inability to earn a living through fishing because of declining catch rates (Fig. 2). These results are consistent with those found in related studies from the Western Indian Ocean, where fishers with fewer livelihood options were more likely to remain in a declining fishery (Cinner et al. 2009, Daw et al. 2012).

In Inhangome, competition over declining resources has led to conflict, most often manifested through the theft of fishing gear and housing material (Fig 2). Most fishers said they did not know why theft was occurring, but a 31-year-old fisher remarked that "some fishers are too ambitious and they catch too many fish to the detriment of the other fishers." During our 2010 research visit, we got to know one of the most successful fishers in Inhangome. He was locally famous for supporting 7 wives, 34 biological children, and 7 adopted children. He owned 3 fishing nets, which he kept in a small hut near the river, making him one of the wealthiest fishers in the community. When we returned in May 2012, we found him in a state of despair. A few weeks before we arrived, the hut containing his nets had been burned down. They had cost him approximately $10,000 \mathrm{MZN}$ each (equivalent to US\$334) and, at the age of 41, he explained, he would never during the remainder of his career be able to earn enough money to replace them. This type of intercommunity conflict, which has also been documented in fishing communities in Cambodia, results in loss of trust, erodes social capital, and thus inhibits adaptive actions that rely on strong community relationships (Marschke and Berkes 2006).

Poverty can lead fishers to remain in a declining fishery and adjust to diminishing returns. Significantly, the most common adaptive strategy in both communities was reducing food consumption (Table 2). The majority of fishers surveyed had experienced food insecurity during the previous year (Fig. 2). Many interview respondents expressed a sense of powerlessness to improve their situation. One 31-year-old fisher from Inhangome hinted at this sense of futility when he stated, "I don't want to make any changes for the future, I just want to think about today." Sen (1999) warns that under persistent deprivation, marginalized people can learn to adapt their hopes and expectations to undesirable conditions. Regardless of context, reducing food consumption should never have to be thought of as a viable adaptive strategy in any community. A final, important point is that although fishers at Zalala Beach and Inhangome are practicing a range of adaptive strategies, both communities remain highly vulnerable to livelihood stressors because of pervasive poverty.

\section{CONCLUSION}

Change is a defining characteristic of coastal social-ecological systems, and human communities have developed strategies for dealing with variability within their system (Ommer 2007). However, the magnitude and speed of contemporary change is challenging even the most robust fishing communities to develop new adaptation strategies (McClanahan and Cinner 2012). Strengthening the capacity of threatened communities to adapt is essential not only for preserving the ecological resilience of marine ecosystems but also for the social services they can generate (Khan and Neis 2010). This paper provides an original contribution by documenting how fishers' are adapting to multiple drivers of change in two communities in Mozambique, and by focusing on factors that facilitate or inhibit adaptive strategies in linked social-ecological systems. We found that specialized fishers' with higher investment in fishing gear and government support chose to adapt by intensifying their fishing efforts, whereas poorer fishers with more livelihood options are adapting through diversification.

Within the livelihood diversification literature, the decision to diversify is often divided into two categories: necessity, which refers to diversification as an involuntary action, and choice, which refers to diversification as a proactive strategy (Ellis 2000). Based on the precept of modernization, which assumes that the progression from a low to a high standard of living involves transition from diversification to specialization, diversification by necessity has frequently been portrayed as a negative action (Ellis 2000). In India, for example, Coulthard (2008) found that specialized Pattinaver fishers saw diversification as a step backward and chose to wait out lean years rather than diversifying. Similarly, fishers at Zalala Beach demonstrated a high sense of occupational pride and indicated their desire to remain in the fishery despite declining catch rates. In contrast, although fishers from Inhangome lack expensive fishing gear and government support, they possess high social capital and occupational multiplicity that helps them adapt. Despite the fact that diversification is often the strategy of the poorest households, we argue that diversification increases adaptive options and therefore places households in good stead during periods of livelihood stress. Further, by participating in a range of fishing and nonfishing related livelihood activities, fishers who diversify reduce fishing pressure, which may contribute to long-term sustainability of the social-ecological system. 
Along the Mozambican coast overfishing is interacting with social, ecological, and economic drivers of change and threatening the sustainability of coastal communities. In response to the diverse, dynamic, and complex nature of these challenges, researchers have suggested that clumsy solutions will be required to strengthen threatened coastal communities (Khan and Neis 2010). Clumsy solutions draw on multiple perspectives, emphasize the importance of fishers' and harvesters' knowledge, and recognize that fisheries problems, and thus solutions, are not static. In Mozambique, where national-scale fisheries programs are hindered by limited resources, understanding and supporting local adaptations will be critical for strengthening communities' capacity to respond to livelihood stressors. Many of the factors that inhibit adaptation in our two research communities (e.g., limited assets, competition over declining resources, and pervasive poverty) are indicators of problems that run deeper. Therefore, our results suggest that nonsectoral interventions that build human and social capital may be more effective in strengthening the livelihoods of coastal communities than those targeting fishing assets alone (Mills et al. 2011).

Our data suggest that it is not always the poorest fishers who are least able to adapt to change, but fishers whose assets are invested in, and who are thus trapped in, a declining fishery. This research represents an important, but preliminary, step toward understanding how local communities are adapting to multiple livelihood stressors along the Mozambican coast. A beneficial next step will be to explore the material outcomes of the adaptive strategies being employed (Coulthard 2012). Can adaptive actions foster both social well-being and ecological sustainability? As Khan and Neis (2010) identify, fisheries and coastal governance often involves difficult choices between equally desirable but contradictory goals. It is important to note that adaptations are complex and context-specific. Understanding the heterogeneity of fishers' responses to livelihood stressors is critical for fostering adaptive capacity in coastal communities, for strengthening fisheries management, and for improving the livelihoods of fishing dependent communities.

Responses to this article can be read online at: http://www.ecologyandsociety.org/issues/responses. $\mathrm{php} / 6408$

\footnotetext{
Acknowledgments:

We are indebted to the fishers and communities who shared their experiences with us. The financial support of the Social Sciences and Humanities Research Council of Canada (SSHRC CGS) and Canadian International Development Agency (CIDA, project number S61268-652) is gratefully acknowledged. The support from University of Eduardo Mondlane's School for Coastal and Marine Science (UEM-ESCMC) and the Institute for the Development of Small-Scale Fisheries (IDPPE) in Quelimane, Mozambique was crucial during field work. The authors are grateful for insightful comments received from Rosemary Ommer and Barbara Neis and two anonymous reviewers.
}

\section{LITERATURE CITED}

Adger, W. N. 2003. Social capital, collective action, and adaptation to climate change. Economic Geography 79:387-404. http://dx.doi.org/10.1111/j.1944-8287.2003.tb00220.x

Adger, W. N., N. W. Arnell, and E. L. Tompkins. 2005. Successful adaptation to climate change across scales. Global Environmental Change 15:77-86. http://dx.doi.org/10.1016/j.gloenvcha.2004.12.005

Allison, E. H., and F. Ellis. 2001. The livelihoods approach and management of small-scale fisheries. Marine Policy 25 (5):377-388. http://dx.doi.org/10.1016/S0308-597X(01)00023-9

Badjeck, M.-C., E. H. Allison, A. S. Halls, and N. K. Dulvy. 2010. Impacts of climate variability and change on fishery-based livelihoods. Marine Policy 34(3):375-383. http://dx.doi. org/10.1016/j.marpol.2009.08.007

Béné, C. 2003. When fishery rhymes with poverty: a first step beyond the old paradigm on poverty in small-scale fisheries. World Development 31(6):949-975. http://dx.doi.org/10.1016/S0305-750X (03)00045-7

Blythe, J. L., G. Murray, and M. S. Flaherty. 2013. Historical perspectives and recent trends on the coastal Mozambican fishery. Ecology and Society 18(4): 65. http://dx.doi.org/10.5751/ ES-05759-180465

Carney, D. 1998. Sustainable rural livelihoods: what contributions can we make? Department for International Development (DFID), London, UK.

Chambers, R., and G. Conway. 1992. Sustainable livelihoods: practical concepts for the $21^{\text {st }}$ century. IDS Discussion Paper 296, Institute of Development Studies, Brighton, Sussex, UK.

Christie, F., and J. Hanlon. 2001. Mozambique and the great flood of 2000. International African Institute, James Curray, Oxford, UK.

Cinner, J., T. Daw, and T. R. McClanahan. 2009. Socioeconomic factors that affect artisanal fishers' readiness to exit a declining fishery. Conservation Biology 23(1):124-130. http://dx.doi. org/10.1111/j.1523-1739.2008.01041.x

Cinner, J. E., C. Folke, T. Daw, and C. Hicks. 2011. Responding to change: using scenarios to understand how socioeconomic factors may influence amplifying or dampening exploitation feedbacks among Tanzanian fishers. Global Environmental Change 21:7-12. http://dx.doi.org/10.1016/j.gloenvcha.2010.09.001

Coulthard, S. 2008. Adapting to environmental change in artisanal fisheries - insights from a South Indian lagoon. Global Environmental Change 18(3):479-489. http://dx.doi.org/10.1016/ j.gloenvcha.2008.04.003

Coulthard, S. 2012. Can we be both resilient and well, and what choices to people have? Incorporating agency into the resilience debate from a fisheries perspective. Ecology and Society 17(1): 4. http://dx.doi.org/10.5751/ES-04483-170104

Daw, T., W. N. Adger, K. Brown, and M. C. Badjeck. 2009. Climate change and capture fisheries: potential impacts, adaptation and mitigation. Pages 107-150 in K. Cochrane, C. De Young, D. Soto, and T. Bahri, editors. Climate change implications for fisheries and aquaculture: overview of current scientific knowledge. Food and 
Agriculture Organization Fisheries and Aquaculture Technical Paper No. 530, FAO, Rome, Italy.

Daw, T. M., J. E. Cinner, T. R. McClanahan, K. Brown, S. M. Stead, N. A. J. Graham, and J. Maina. 2012. To fish or not to fish: factors at multiple scales affecting artisanal fishers' readiness to exit a declining fishery. PLoS One 7(2):e31460. http://dx.doi. org/10.1371/journal.pone.0031460

de Haan, L., and A. Zoomers. 2005. Exploring the frontier of livelihoods research. Development and Change 36(1):27-47. http:// dx.doi.org/10.1111/j.0012-155X.2005.00401.X

Ellis, F. 2000. Rural livelihoods and diversity in developing countries. Oxford University Press, Oxford, UK.

Food and Agriculture Organization (FAO). 2007. Fisheries country profile: Mozambique. FAO, Rome, Italy.

Food and Agriculture Organization (FAO). 2011. FishStat Plus: capture production 1950-2009. FAO, Rome, Italy. http://www.fao. org/fishery/statistics/software/fishstat/en

Government of Mozambique (GoM). 2011. Poverty reduction action plan (PARP) 2011-2014. GoM, Maputo, Mozambique.

Hervey, A., and J. Blythe. 2013. Reducing climate change vulnerability in Mozambique: from policy to practice. Pages 238-257 in D. Held, C. Roger, and E.-M. Nag, editors. Climate governance in the developing world. Polity Press, London, UK.

Instituto de Desenvolvimento de Pesca de Pequena Escala (IDPPE). 2009. Recenseamento da pesca artesanal 2007. IDPPE, Maputo, Mozambique.

Intergovernmental Panel on Climate Change (IPCC). 2007. Climate change 2007: impacts, adaptation and vulnerability. $\mathrm{M}$. Parry, O. Canziani, J. Palutikof, O. van der Linden, C. and Hanson, editors. Contribution of Working Group II to the Fourth Assessment Report of the Intergovernmental Panel on Climate Change, Cambridge University Press, Cambridge, UK.

Jacquet, J. L., H. Fox, H. Motta, A. Ngusaru, and D. Zeller. 2010. Few data but many fish: marine small-scale fisheries catches for Mozambique and Tanzania. African Journal of Marine Science 32(2):197-206. http://dx.doi.org/10.2989/1814232X.2010.501559

Jentoft, S., and R. Chuenpagdee. 2009. Fisheries and coastal governance as a wicked problem. Marine Policy 33:553-560. http://dx.doi.org/10.1016/j.marpol.2008.12.002

Khan, A. S., and B. Neis. 2010. The rebuilding imperative in fisheries: clumsy solutions for a wicked problem? Progress in Oceanography 87:347-356. http://dx.doi.org/10.1016/j.pocean.2010.09.012

Lopes, S. and H. Gervásio. 1999. Co-management of small-scale fisheries in Mozambique: a case study of Kwirikwidge fishing community in Angoche District, Nampula Province. International Workshop on Fisheries Co-Management, Penang, Malaysia.

Lotze, H. K., H. S. Lenihan, B. J. Bourque, R. H. Bradbury, R. G. Cooke, M. C. Kay, S. M. Kidwell, M. X. Kirby, C. H. Peterson, and J. B. C. Jackson. 2006. Depletion, degradation, and recovery potential of estuaries and coastal seas. Science 312 (5781):1806-1809. http://dx.doi.org/10.1126/science.1128035
Marschke, M. J., and F. Berkes. 2006. Exploring strategies that build livelihood resilience: a case from Cambodia. Ecology and Society 11(1): 42. [online] URL: http://www.ecologyandsociety. org/vol11/iss1/art42/

McClanahan, T. R. and J. E. Cinner. 2012. Adapting to a changing environment: confronting the consequences of climate change. Oxford University Press, Oxford, UK.

McGoodwin, J. R. 2001. Methods for studying the cultures of small-scale fishing communities. Pages 57-71 in J. R. McGoodwin, editor. Understanding the cultures of fishing communities: a key to fisheries management and food security. FAO Technical Paper 401, Food and Agriculture Organization, Rome, Italy.

Menezes, A., R. Smardon, and T. de Almeida. 2009. The changing dynamics of local institutions in fishing communities in Mozambique: responses to policy-public participation and decision making. Environmental Practice 11(1):32-51. http://dx. doi.org/10.1017/S1466046609090085

Millennium Ecosystem Assessment (MEA). 2005. Ecosystems and human well-being: health synthesis. Island, Washington, D.C., USA.

Mills, D., C. Béné, S. Ovie, A. Tafida, F. Sinaba, A. Kodio, A. Russell, N. Andrew, P. Morand, and J. Lemoalle. 2011. Vulnerability in African small-scale fishing communities. Journal of International Development 23(2):308-313. http://dx.doi. org/10.1002/jid.1638

Muthiga, N., A. Costa, H. Motta, C. Muhando, R. Mwaipopo, and M. Schleyer. 2008. Status of coral reefs in East Africa: Kenya, Tanzania, Mozambique and South Africa. Pages 91-104 in C. Wilkinson, editor. Status of coral reefs of the world: 2008. Global Coral Reef Monitoring Network and Reef and Rainforest Research Centre, Townsville, Australia.

Nielsen, J. Ø., and A. Reenberg. 2010. Cultural barriers to climate change adaptation: a case from northern Burkina Faso. Global Environmental Change 20:142-152. http://dx.doi.org/10.1016/j. gloenvcha.2009.10.002

O’Brien, K. L., and R. M. Leichenko. 2000. Double exposure: assessing the impacts of climate change within the context of economic globalization. Global Environmental Change 10:221-232. http://dx.doi.org/10.1016/S0959-3780(00)00021-2

Ommer, R. 2007. Coasts under stress: restructuring and socialecological health. McGill-Queen's University Press, Montreal, Quebec, Canada.

Ommer, R., R. I. Perry, K. L. Cochrane, and P. Cury. 2011. World fisheries: a social-ecological analysis. Wiley-Blackwell, Oxford, UK. http://dx.doi.org/10.1002/9781444392241

Osbahr, H., C. Twyman, W. N. Adger, and D. S. G. Thomas. 2010. Evaluating successful livelihood adaptation to climate variability and change in southern Africa. Ecology and Society 15(2): 27. [online] URL: http://www.ecologyandsociety.org/vol15/iss 2/ $\underline{\operatorname{art} 271}$

Perry, R. I., R. E. Ommer, E. Allison, M.-C. Badjeck, M. Barange, L. Hamilton, A. Jarre, R. A. Quiñones, and U. R. Sumaila. 2010. Interactions between changes in marine ecosystems and human 
communities. Pages 221-252 in M. Barange, J. G. Field, R. P. Harris, E. E. Hofmann, R. I. Perry, and C. Werner, editors. Marine ecosystems and global change. Oxford University Press, Oxford, UK. http://dx.doi.org/10.1093/acprof:oso/9780199558025.003.0008

Pitcher, M. A. 2002. Transforming Mozambique: the politics of privatization, 1975-2000. Cambridge University Press, Cambridge, UK. http://dx.doi.org/10.1017/CBO9780511491085

Pollnac, R. B., R. S. Pomeroy, and I. H. T. Harkes. 2001. Fishery policy and job satisfaction in three southeast Asian fisheries. Ocean and Coastal Management 44:531-544. http://dx.doi. org/10.1016/S0964-5691(01)00064-3

Scoones, I. 2009. Livelihoods perspective and rural development. Journal of Peasant Studies 36(1):171-196. http://dx.doi. org/10.1080/03066150902820503

Sen, A. 1999. Development as freedom. Oxford University Press, Oxford, UK.

Smit, B., and J. Wandel. 2006. Adaptation, adaptive capacity and vulnerability. Global Environmental Change 16(3):282-292. http:// dx.doi.org/10.1016/j.gloenvcha.2006.03.008

United Nations Development Programme (UNDP). 2013. Human development report 2013. The rise of the south: human progress in a diverse world. UNDP, New York, New York, USA.

van Logchem, B., and R. Brito, editors. 2009. Synthesis report. INGC climate change report: study on the impacts of climate change on disaster risk in Mozambique. INGC, Maputo, Mozambique. 